\title{
Varroa jacobsoni INFESTATION OF ADULT AFRICANIZED AND ITALIAN HONEY BEES (Apis mellifera) IN MIXED COLONIES IN BRAZIL
}

\author{
Geraldo Moretto and Leonidas João de Mello Jr.
}

\begin{abstract}
Different levels of infestation with the mite Varroa jacobsoni have been observed in the various Apis mellifera races. In general, bees of European races are more susceptible to the mite than African honey bees and their hybrids. In Brazil honey bee colonies are not treated against the mite, though apparently both climate and bee race influence the mite infestation. Six mixed colonies were made with Italian and Africanized honey bees. The percentage infestation by this parasite was found to be significantly lower in adult Africanized $(1.69 \pm 0.44)$ than Italian bees $(2.79 \pm 0.65)$. This ratio was similar to that found in Mexico, even though the Africanized bees tested there had not been in contact with varroa, compared to more than 20 years of the coexistence in Brazil. However, mean mite infestation in Brazil on both kinds of bees was only about a third of that found in Mexico.
\end{abstract}

\section{INTRODUCTION}

The mite Varroa jacobsoni, initially an ectoparasite of the Asian bee Apis cerana, was first found on Apis mellifera in the 1950s. When this mite only parasitized Apis cerana, it remained limited to the Asian continent. However, a rapid man-aided dispersal was observed soon after contact with Apis mellifera (De Jong, 1990).

Since the contact between varroa and Apis mellifera, serious problems have been experienced worldwide in apiculture. The effects of the parasite on honey bees range from weakening to death of parasitized colonies, with the intensity of the problem being directly related to the level of infestation (De Jong, 1990).

Climate and Apis mellifera race were found to be important factors that affect the development of this parasite (De Jong et al., 1984; Moretto et al., 1991; De Jong and Soares, 1997). Under the climatic conditions of Europe and other temperate regions, varoosis made beekeeping impracticable without the use of acaricides. However, in regions with a subtropical climate, such as Ribeirão Preto, São Paulo State, Brazil, infestation has stabilized at low levels, causing no serious damage to apiculture (Gonçalves, 1987).

Among the different types of Apis mellifera, Africanized bees show great resistance to varroa compared to bees of European races. One of the factors that is thought to be involved in this resistance is the fact that the reproductive ability of varroa females is known to be lower in Africanized bees than in European bees (Camazine, 1986; Moretto, 1988).

Peng et al. (1987) observed that A. cerana has a strong defense mechanism against Varroa jacobsoni. When

Centro de Ciências Exatas e Naturais, Universidade Regional de Blumenau 89.100-971 Blumenau, SC, Brasil. Send correspodence to G.M. E-mail: gmoretto@furb.rct-sc.br
A. cerana workers were artificially infested with varroa females, $99 \%$ succeeded in ridding themselves of the parasite by performing body movements that expelled or removed it from their body. It was also observed that many of the mites that left the host worker were killed by the infested worker itself or its fellow workers. Defense mechanisms against the mite similar to those of Apis cerana have been identified in Africanized bees. Moretto et al. (1993) observed that $40 \%$ of Africanized bees rid themselves of the parasite when workers of 20 Africanized bee colonies were artificially infested. Correa-Marques (1996), in a study of mites collected from the bottom of Africanized bee colonies, noted the occurrence of mutilations in several parts of their body, indicating possible attacks by the workers.

The objective of the present study was to determine the influence of bee race on the extent of Varroa jacobsoni infestation in Apis mellifera bee colonies containing both Africanized and pure Italian bees.

\section{MATERIAL AND METHODS}

This study was conducted on six five-frame colonies (nuclei) of Apis mellifera bees whose population consisted of a mixture of Africanized and Italian bees. At the beginning of the study an Apis mellifera ligustica queen (instrumentally inseminated with sperm from males of the same race) originating from a commercial apiary from Mexico was introduced into each bee colony.

Colonies consisting of both races were artificially formed by exchanging worker brood combs between colonies of the two races, i.e., every week combs containing emerging bee brood were removed from Africanized bee colonies and introduced into the Italian colonies for the study. Thus, it was possible to maintain colonies with approximately equal proportions of workers of both bee races. Workers of the two racial types were easily distinguished by color, Italians were yellow and Africanized were dark in color. 
The influence of bee race on the mechanism of defense against Varroa jacobsoni was determined by measuring the degree of infestation with this mite in each bee race by the method of De Jong et al. (1982). Samples of 150 workers of each bee race were collected from each bee colony every two weeks from August 1997 to February 1998. The workers were collected individually with the aid of a small forceps and stored separately by race and colony in flasks containing $70 \%$ alcohol.

The effect of bee race on the degree of infestation with Varroa jacobsoni was analyzed statistically by ANOVA according to the following model:

$$
Y i j=\mu+\alpha i+\varepsilon i j
$$

where: Yij = observation concerning the bee race of each colony; $\mu=$ overall mean effect; $\alpha i=$ effect of bee race; $\varepsilon \mathrm{ij}=$ errror.

The Student $t$-test was used to determine the effect of bee race for each of the six colonies studied. Data were transformed to arc-sin before the application of both tests.

\section{RESULTS AND DISCUSSION}

The degree of infestation was higher in the Italian than in the Africanized bees during the entire study period (Figure 1). Also, infestation showed similar behavior in the two bee races. Fluctuations in the degree of infestation were possibly due to fluctuations in the amount of worker and/or drone brood that occurred during the study period.

The mean degree of infestation (percentage) with varroa for the entire study period was $2.79 \pm 0.65$ for Italian bees and $1.69 \pm 0.44$ for Africanized bees. The Italian bees were significantly more infested than Africanized bees (ANOVA, $\mathrm{F}=12.45 ; \mathrm{P}<0.001$ ). Among the six colonies studied, only one showed equal infestation for the two bee races. In all the other colonies, the Italian bees were significantly more heavily infested with the parasite (Table I).

Since Varroa jacobsoni first contacted Africanized

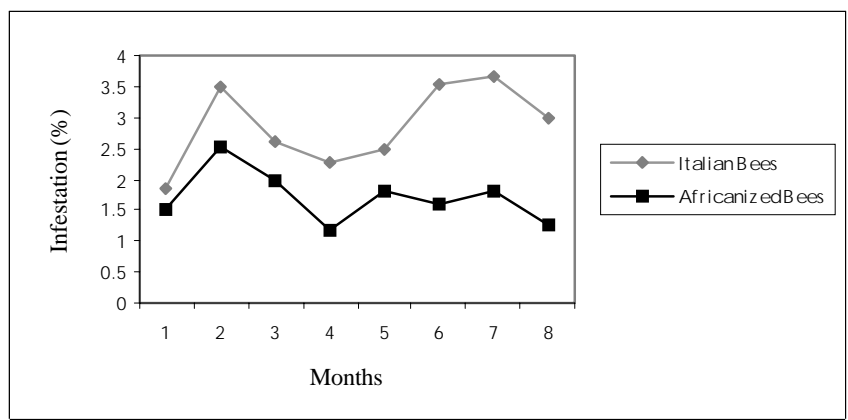

Figure 1 - Monthly census number of Varroa jacobsoni per 100 adult bees in Italian and Africanized honey bees reared in the same beehive.
Table I - Percentage of workers parasitized by Varroa jacobsoni in Italian and Africanized honey bees reared in the same beehive.

\begin{tabular}{|cccl|}
\hline & \multicolumn{3}{c|}{ Type of Bee } \\
\cline { 2 - 3 } Colony & Italian & Africanized & $t$-value \\
\hline 1 & 2.65 & 1.39 & $2.75^{* *}$ \\
2 & 1.50 & 1.60 & $0.65 \mathrm{~ns}$ \\
3 & 1.97 & 0.95 & $2.00^{*}$ \\
4 & 2.93 & 2.02 & $2.10^{*}$ \\
5 & 3.80 & 2.20 & $2.42^{* *}$ \\
6 & 3.86 & 2.01 & $2.70^{* *}$ \\
\hline
\end{tabular}

$*=\mathrm{P}<0.05 ; * *=\mathrm{P}<0.001 . \mathrm{ns}=$ Not significant

bees it has been possible to observe the greater resistance of this bee race to the parasite (De Jong et al., 1984; Camazine, 1986). Thus, the effect of bee race is of crucial importance to the development of varroosis.

Moretto et al. (1993) reported that when Africanized and Italian worker bees were artificially infested with adult Varroa jacobsoni females they immediately reacted to the presence of the parasite, performing strong body movements that removed the mite within a few minutes after infestation.

The lower degree of varroa infestation among Africanized bees in bee colonies containing both Africanized and Italian workers is related to the defensive capacity of these bees against this parasite. The body movements of Africanized worker bees when artificially parasitized with varroa females observed by Moretto et al. (1993) apparently are performed under natural conditions.

Engels et al. (1986) studied the degree of Varroa jacobsoni infestation in Carniolan and Africanized honey bees, under the climate conditions of the State of São Paulo, Brazil. During this study the varroa infestation was higher in the pure Carniolan than in the Africanized bees. However, during the (subtropical) winter, when the Carniolan colonies had to be reinforced with Africanized bee brood, the level of varroa infestation was similar to that of the Africanized colonies.

In a study by Gusman-Novoa et al. (1996) in Mexico, with adult Africanized and European bees from Mexico, maintained in the same beehive, the level of infestation with the mite Varroa jacobsoni was twice as high on Africanized bees, compared to European bees, approximately 5 and $10 \%$, respectively. The infestation on both bee races in Mexico was about three times that found in our study in Brazil. When these two types of bees are compared in Brazil, it can be seen from our data that European bees are infested about $65 \%$ more frequently than Africanized bees, similar to the difference found in Mexico.

In Brazil, the mite Varroa jacobsoni was introduced in the early seventies and within less than ten years it had already spread throughout all the regions of the country, 
parasitizing all honey bee colonies. Thus, the Africanized bees of Brazil have been in contact with the varroa for approximately 20 years. In the study by Gusman-Novoa et al. (1996), the Africanized bees were obtained from a region in Mexico that was still free from the mite, indicating that these bees had never been in contact with this parasite. The similar relative response (when compared to European bees) to Varroa jacobsoni by Africanized bees that have been in contact with it for 20 years in Brazil and by those which have been in contact with it for the first time in Mexico suggests that Africanized bees are preadapted to this mite.

\section{ACKNOWLEDGMENTS}

This study was supported by the Conselho Nacional de Desenvolvimento Cientifíco e Tecnológico (CNPq) and the Fundo de Apoio à Pesquisa (FUNAPES) from the Universidade Regional de Blumenau.

\section{RESUMO}

Desde o contato inicial entre o ácaro Varroa jacobsoni e a abelha Apis mellifera, diferentes níveis de infestação foram verificados entre as diversas raças dessa espécie de abelhas. O presente trabalho teve como objetivo verificar o grau de infestação determinado pelo acaro Varroa jacobsoni em abelhas Apis mellifera, africanizadas e italianas puras, quando criadas numa mesma colméia. Para isso, o grau de infestação foi obtido em seis colônias de abelhas constituídas de operárias de ambas as raças. $\mathrm{O}$ resultado de dezesseis repetições mostrou que as abelhas africanizadas foram menos infestadas que as abelhas italianas. Esse resultado sugere que, nas condições naturais de infestação, as abelhas africanizadas são mais defensivas ao parasita Varroa jacobsoni, garantindo a essa raça de abelhas a resistência à praga varroosis.

\section{REFERENCES}

Camazine, S. (1986). Differential reproduction of the mite Varroa jacobsoni, on Africanized and European honeybees. Ann. Entomol. Soc. Am 79: 801-803.

Correa-Marques, M.H. (1996). Aspectos da resistência da abelha Apis mellifera ao ácaro Varroa jacobsoni no Brasil. M.Sc. thesis, Faculdade de Filosofia, Ciências e Letras de Ribeirao Preto, USP.

De Jong, D. (1990). Mites: Varroa and other parasites of brood. In: Honey Bee Pests, Predators and Diseases (Morse, R.A. and Nowogrodski, R., eds.). Cornell University Press, Ithaca, pp. 200-218.

De Jong, D. and Soares, A.E.E. (1997). An isolated population of Italian bees that has survived Varroa jacobsoni infestation without treatment for over 12 years. Am. Bee J. 137: 742-745.

De Jong, D., Roma, D.A. and Gonçalves, L.S. (1982). A comparative analysis of shaking solutions for the detection of Varroa jacobsoni on adult honey bees. Apidologie, 13: 297-306.

De Jong, D., GonçaIves, L.S. and Morse, R.A. (1984). Dependence of climate on the virulence of Varroa jacobsoni. Bee World 65: 117-121.

Engels, W., Gonçalves, L.S., Steiner, J., Buriolla, A.H. and CavicchioIssa, M.R. (1986). Varroa-Befall von Carnica-Volkern in Tropenklima. Apidologie 17: 203-216

Gonçalves, L.S. (1987). O combate a Varroa em todo o mundo. Apic. Bras. 31: $31-35$.

Gusman-Novoa, E., Sanches, A., Page, R.E. and Garcia, T. (1996). Susceptibility of European and Africanized honeybees (Apis mellifera) and their hybrids to Varroa jacobsoni Oud. Apidologie 27: 97-103.

Moretto, G. (1988). Efeitos de diferentes regiões climáticas brasileiras e de tipos raciais de abelhas Apis mellifera na dinâmica populacional do ácaro Varroa jacobsoni. M.Sc. thesis, Faculdade de Medicina de Ribeirão Preto, USP.

Moretto, G., Gonçalves, L.S., De Jong D. and Bichuette, M.Z. (1991) The effects of climate and bee race on Varroa jacobsoni Oud infestations in Brazil. Apidologie 22: 197-203.

Moretto, G., Gonçalves, L.S. and De Jong, D. (1993). Heritability of Africanized and European honeybee defensive behavior against the mite Varroa jacobsoni. Rev. Bras. Genét. 16: 71-77.

Peng, Y.S., Fang, Y., Xu, S. and Ge, L. (1987). The resistance mechanism of the Asian honeybee Apis cerana Fabr. to an ectoparasitic mite Varroa jacobsoni Oudemans. J. Invertebr. Pathol. 19: 54-60.

(Received May 14, 1998) 
